This is an electronic reprint of the original article. This reprint may differ from the original in pagination and typographic detail.

Author(s): Saarikallio, Matti; Tyrväinen, Pasi

Title: $\quad$ Following the Money: Revenue Stream Constituents in Case of Within-firm Variation

Year: $\quad 2014$

Version:

Please cite the original version:

Saarikallio, M., \& Tyrväinen, P. (2014). Following the Money: Revenue Stream Constituents in Case of Within-firm Variation. In C. Lassenius, \& K. Smolander (Eds.), Software Business. Towards Continuous Value Delivery : 5th International Conference, ICSOB 2014, Paphos, Cyprus, June 16-18, 2014. Proceedings (pp. 88-99). Springer. Lecture Notes in Business Information Processing, 182. https://doi.org/10.1007/978-3-319-08738-2_7

All material supplied via JYX is protected by copyright and other intellectual property rights, and duplication or sale of all or part of any of the repository collections is not permitted, except that material may be duplicated by you for your research use or educational purposes in electronic or print form. You must obtain permission for any other use. Electronic or print copies may not be offered, whether for sale or otherwise to anyone who is not an authorised user. 


\title{
Following the Money: Revenue Stream Constituents in Case of Within-firm Variation
}

\author{
Matti Saarikallio and Pasi Tyrväinen \\ matti@saarikallio.net, pasi.tyrvainen@jyu.fi
}

\begin{abstract}
The idea of this paper stems from the perception that the concept of revenue stream requires clarification and further division to be applicable to businesses with high internal variation in their methods of capturing revenue. Current study sets out to investigate the concept of revenue stream through an overview of previous literature and a case study to demonstrate how revenue streams of a b2b (business-to-business) software service firm can be analyzed by elaborating the concept further. The aim is to answer the following research questions: 1) What are the relevant constituents of the revenue stream concept within a b2b software services firm? 2) How revenue stream as part of the business model can be analyzed within a firm? This exploratory study contributes to the business model literature by investigating the concept of revenue stream and revenue stream type as managerial tools to better understand the business under investigation. The study further attempts to contribute to the decomposition of the revenue stream concept by exploring its constituents in the context of b2b software business. It is suggested that revenue streams in this context should be approached based on sub-component level analysis where the reason and source dimensions create a matrix of analysis cells from which revenue stream types emerge based on similarities in the method of the revenue streams. Based on previous literature and empirical study, it is further suggested that the revenue stream has three main constituents or sub-components: 1) the source of revenue, 2) the reason for revenue and 3) the method of revenue.
\end{abstract}

Key words. Business model, revenue stream type, software service company, $\mathrm{b} 2 \mathrm{~b}$, source of revenue, reason for revenue, method of revenue 


\section{Introduction and Background}

\subsection{Business Model Research}

Through experience, business practitioners have mental models about their business, but such mental model can only be communicated and modified once it has been made explicit as a business model [1]. Research about business models has been around for a long time in the domain of software firms. Still, research knowledge about business model is disjointed and unclear [2]. While there is not yet a common understanding, ontologically business model has been suggested to reside in the middle ground between business strategy and business processes [3].

There are various ways to conduct research relating to business models. Research sub-domains can be divided into definitions, components, taxonomies, representations, change methodologies, and evaluation models [4]. The goal of component research is to further decompose the business model concept into its fundamental constructs [4].

The business model concept and its sub-components are used often as a tool to plan and define the business model of new startups. For example Mahadevan [5] uses the term revenue stream to mean the plan for revenue generation. However, business model can also be used to analyze an existing established firm to gain understanding about the de facto business model in place. Such an approach has been taken for example by Rajala, Rossi \& Tuunainen [6] in their software business evaluation framework. The idea for the current paper stems from the challenges in analyzing an existing firm's business model's revenue streams when the firm under investigation has multiple customers and offerings with high variability in revenue stream configurations.

\subsection{Revenue Stream}

Most business model conceptualizations include a financial aspect relating to the money that flows into the company. Business model literature is filled with various terms used for these aspect such as: revenue stream, revenue, sources of revenue, revenues, revenue model, revenue mix, revenue side of the business, revenue source, revenue logic, revenue earning logic, revenue mechanism, income model and earnings $\operatorname{logic}[5][7][8][30][9][10][6][18][11][23][12][13][14][15]$. Table 1 summarizes the terms and what they are suggested to mean in the context of business model. The same unclarity that exists for the business model appears to be present for the revenue related sub-components as well. There seems to be a common theme, but not a clear agreement on the terminology.

Zott and Amit [16] have suggested that revenue model complements a business model design in similar way as pricing strategy complements product design. This can be a useful analogy but in the same way as business model is quite an abstract concept when compared to product design, revenue model is very much as abstract compared to pricing strategy. Revenue stream on the other hand seems to have potential to be 
defined as a more tangible and measurable object of study as it can be reduced to the concrete idea of money flowing into the company. For this reason of seeking conceptual clarity, this paper focuses on the revenue stream as the main concept of business model and also adopts the approach used in the business model canvas concept suggested by Osterwalder and Pigneur [17].

Table 1. There is a multitude of partially overlapping revenue related business model concepts.

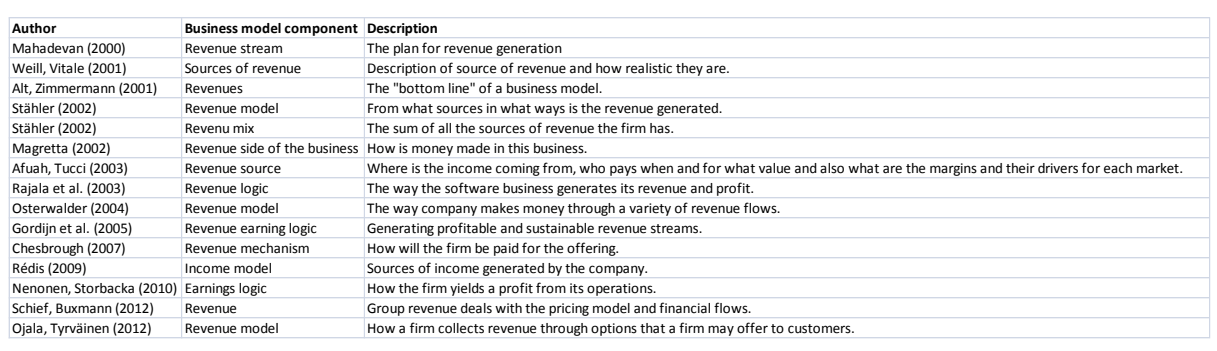

\subsection{Aims of the Paper}

Thus, the current study aims to contribute to the research domain of business model components by investigating a sub-component referred to as revenue stream. For example Osterwalder [18] sees the revenue streams as one of the key parts of the business model. He uses the broader term revenue model to mean a collection of revenue streams within a company.

Osterwalder and Pigneur [17] have claimed that a business model can have two different types of revenue streams, namely transaction revenues and recurring revenues. While this is true in simple business models it is highly unlikely that such a simplification is enough to fully explain the revenue stream sub-component of the business model in the more complicated case.

Shafer, Smith, Linder [19] cite a study by Linder and Cantrell [20] which states that $62 \%$ of executives had a difficult time describing how money is made in their company. This could indicate the complexity of the typical revenue models or that there is a lack of proper conceptualization. Either way this supports the relevance of the current paper's interest area.

This paper aims to clarify the revenue stream component by evaluating the revenue model of a case company which has multiple and variable revenue stream configurations and suggest an answer to the question: 1) what are the relevant constituents of the revenue stream concept within a b2b software services company. Further the study attempts to answer the question: 2) how revenue stream as part of the business model can be analyzed within a firm.

\subsection{Revenue Stream Framework}

Framework to analyze the case study data is suggested based on existing literature. It includes three key parts that must be addressed to explain a revenue stream. These constituents are the source of the revenue stream, the reason for the revenue stream 
and the concrete description of the method of capturing the revenue which is called here the method of revenue. This framework builds upon Rajala, Rossi, Tuunainen and Vihinen [21] who suggest that approaches for capturing revenue can have differences in methods of pricing, sources of revenue and the products and services being sold. Similarly in context of business model innovation, revenue model innovations include as key parts offering reconfiguration and pricing models [22]. Chesbrough [23] uses the term revenue mechanism which is by definition comparable to method of revenue. Figure 1 illustrates the suggested model.

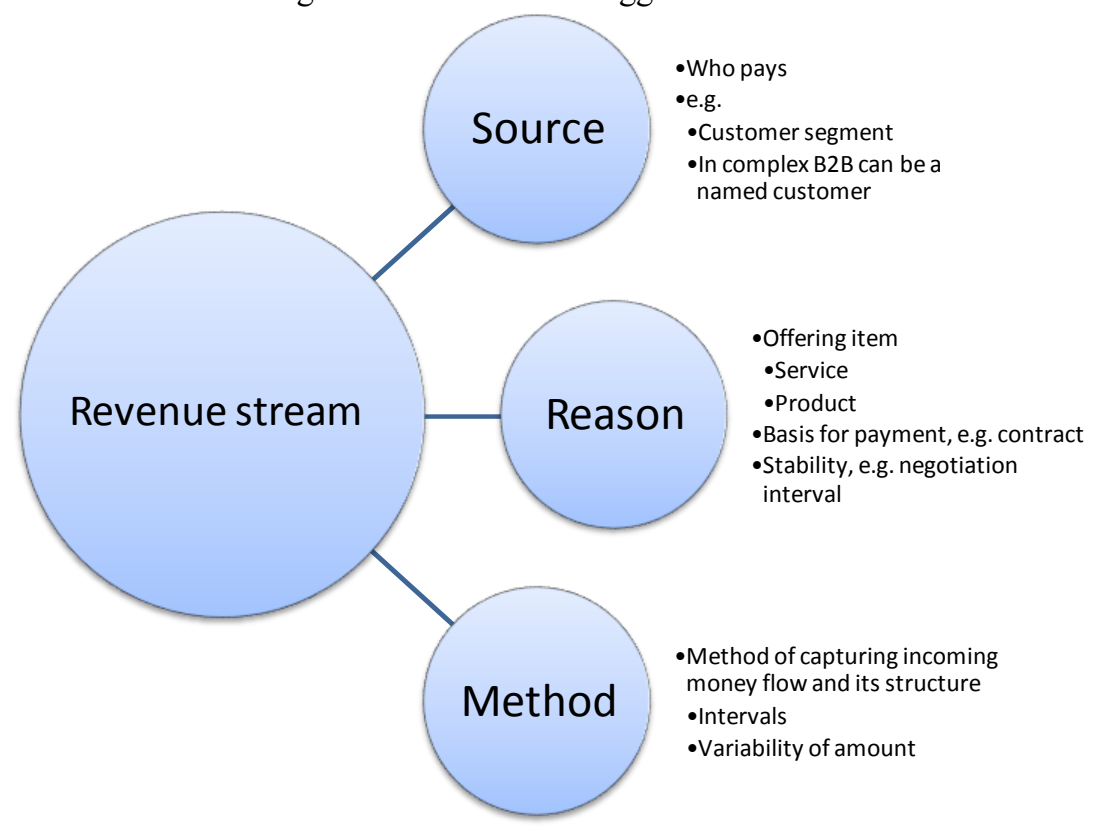

Fig. 1. Suggested decomposition of revenue stream

\section{Methodology}

\subsection{Exploratory Case Study}

Yin [24] suggests using a case study design when trying to answer how or why questions and attempting to cover contextual conditions relevant to the phenomenon. In the current study attempt is made to understand how revenue stream as part of the business model can be analyzed in the context of a specific b2b software service firm.

When seeking to clarify the concept of revenue stream and related subcomponents, it was necessary to analyze the patterns underlying them and it was required to gain an in-depth understanding. Qualitative research approach was chosen 
to improve understanding of the investigated phenomenon [25]. The chosen research strategy was a single case study in a company that is considered a representative example, because it had enough complexity and variation in forms of multiple revenue stream combinations. Because a case study research strategy focuses on understanding the dynamics present in a single setting [26], it was a good approach in exploring the business model sub-component and how it can be analyzed in a real-life setting in a within-firm context. Thus, research strategy was that of a single case study. Eisenhardt [26] has suggested that instead of selecting cases at random, extreme examples are appropriate when seeking to extend theory, which is the goal in the exploratory research that this paper undertakes. Because a lot of the existing literature considers cases where there is one revenue model per business model, an extreme example deviating from the norm would be a case with multiple co-existing revenue models and high within-firm variation in the revenue streams. The selected case meets these criteria.

\subsection{Case Firm}

The chosen case firm operates in the telecom operator software market. This market had only 196 companies offering software product or service offerings in 2006 with a volume just under $\$ 30$ billion [27]. Using the terminology from Luoma, Frank \& Pulkkinen [27] the firm can be classified as a generic telco vendor. It can be predicted that this kind of firm would have a lot of variation in the revenue streams, because of the breadth of operations.

The analyzed case firm serves telecom operator customers by offering BSS (business support system) solutions. The solutions typically contain a service contract which is one side of the business and making continuous customer specific modifications is an additional way to generate revenue. New customers are a rare occasion and typically some sort of penetration pricing is used for initial deliveries. This is possible due to heavy vendor lock-in that is gained once the delivery is completed. The investigated firm has out of 150 people about 80 working in the investigated business unit. It was established in 1995 and has international customers. Relevant customer count is around ten, but three customers produce majority of the revenue. The firm is organized into customer serving teams with minor common functions. R\&D, and marketing and sales departments are manned in ad-hoc manner and no organization exists for these functions. This has given rise to a very variable culture across customer serving teams and most interestingly to this paper it has given rise to a multitude of methods for revenue capture. The complexity of the case makes it a useful context to investigate revenue stream variation.

\subsection{Data Collection}

The main portion of the data was gathered using semi-structured interviews. Twelve people in corporate and business unit management and account management positions were interviewed to find out the current revenue streams of different customer accounts and the various offerings and revenue capture methods for each. The 
interviews lasted from one to three hours each and some were conducted in two separate sessions, because of scheduling challenges. In addition to revenue model specific questions, the understanding of the case was further widened by questions relating to general business model utilizing the business model canvas framework [17]. All interviews were recorded and transcribed. The interviews were scheduled close to each other during a period of one month. Close scheduling was done in order to avoid participants from influencing each others' answers. Some details were clarified by additional short discussions to avoid false interpretations.

In addition to the interviews, access was gained to written materials, mainly contracts and offers made by the case firm. This helped to solidify the actuality of contractual relations with case firm's customers in situations where the informants were unable to remember the details in full.

Data was analyzed using qualitative content analysis method with three analytical procedures of summary, explication and structuring as suggested by Kohlbacher [28]. The transcribed interview data was processed by summarizing the key themes to capture the main ideas from the informants. These themes were then used as a basis for further explication of the data. Dimensions of structuring became apparent from the data and the results are presented within those dimensions.

\section{Results}

\subsection{Source}

The collected data indicated that one explanation for the large revenue stream variation was the source of revenue, namely the customer or customer segment. As one informant put it: "Typically if they have an organization change then the desired invoicing [method] changes." Thus, a big factor affecting the revenue stream is the customer and their needs. This can be partially due to unbalanced negotiation power between the parties. The dynamic nature of the customer means that the revenue stream is also dynamic in nature. When the source of the stream is dynamic it is reflected in the revenue stream. Within the case firm five different sources of revenue were detected. Four of them were different medium to large companies. The fifth source was a group of small companies. The group was analyzed together as one revenue source, because there were no differences from revenue stream point of view.

All the revenue streams in the current case were negotiated separately on a customer by customer basis as a whole and in some customer accounts different parties were involved in negotiating the managed services and the software development agreements. Actually having to negotiate the pricing in each revenue stream added to the complexity of the sales process. The lack of a price list was mostly due to lack of product management efforts in general. The extent of customer specific negotiations suggests that the customer will have a great impact on the revenue stream making it a differentiating dimension. The customer negotiation intervals also have an effect on the predictability of revenue. 


\subsection{Reason}

While source of revenue was a significant explanatory factor for the variation there were also differences in revenue streams originating from one source and it could be seen that the variation was dependent on the reason for revenue. Reason for revenue can be considered to be the offering item which is the product or service and has in most cases a contractual basis. In the current case 9 different reasons were identified from the interviews. They were: billing manager service, customer care system, order entry system, billing system, keeping the systems running, enterprise resource planning system, system development, consulting/analysis. Additionally the firm offers fixed price delivery projects for new customers before the relationship progresses into so-called operative mode. However, no such delivery was ongoing during the interviews and therefore this aspect was excluded from the study. Focus is on the current customer relationships.

Revenue streams based on different offerings varied in terms of packaging level. The revenue streams whose reason for revenue was system licensing or maintenance service offerings were sold as a complete package. On the other hand those streams whose reason for revenue was system development and customization activities contained various configurations based on customer specific needs.

As mentioned earlier, the source of revenue dimension had a somewhat dynamic nature meaning that the needs change over time. Similarly there was dynamism in the reason dimension. It was clear that the offerings were not static. There was also a preference towards generating one type of revenue over the other. An informant commented that they try to push more towards the model where the development is less and maintenance is more: "It's changing towards the direction where maintenance portion is growing; it also has the best upside, because tools are automated." This indicates that the reason for revenue -dimension is also dynamic in nature.

\subsection{Method}

The method of revenue dimension for each stream had differences across streams but similarities as well. Therefore the analysis within this dimension is more involved. In table two the method is described for each revenue stream that is considered unique. In the current case, each revenue source can be considered to originate unique streams compared to other sources, but multiple reasons can exist for the same stream and those reasons can have the same method, so they are combined here into cells depicted in table two.

\subsection{Analysis Matrix}

It proved useful to present the data in a matrix of reason vs. source where for each cell of the matrix the method of revenue stream was considered. If the reasons were contributing to the same revenue stream they were combined together. This way 11 revenue streams (separate money flows) were identified. 
Further looking at these 11 revenue streams and their differences, they could be grouped into four revenue stream types that were considered as unique in the sense that they had a lot of similarities in the method dimension. The four different revenue stream types were given designations A, B, C and D (see table 2).

Table 2. Revenue stream types were grouped based on similar structure of revenue

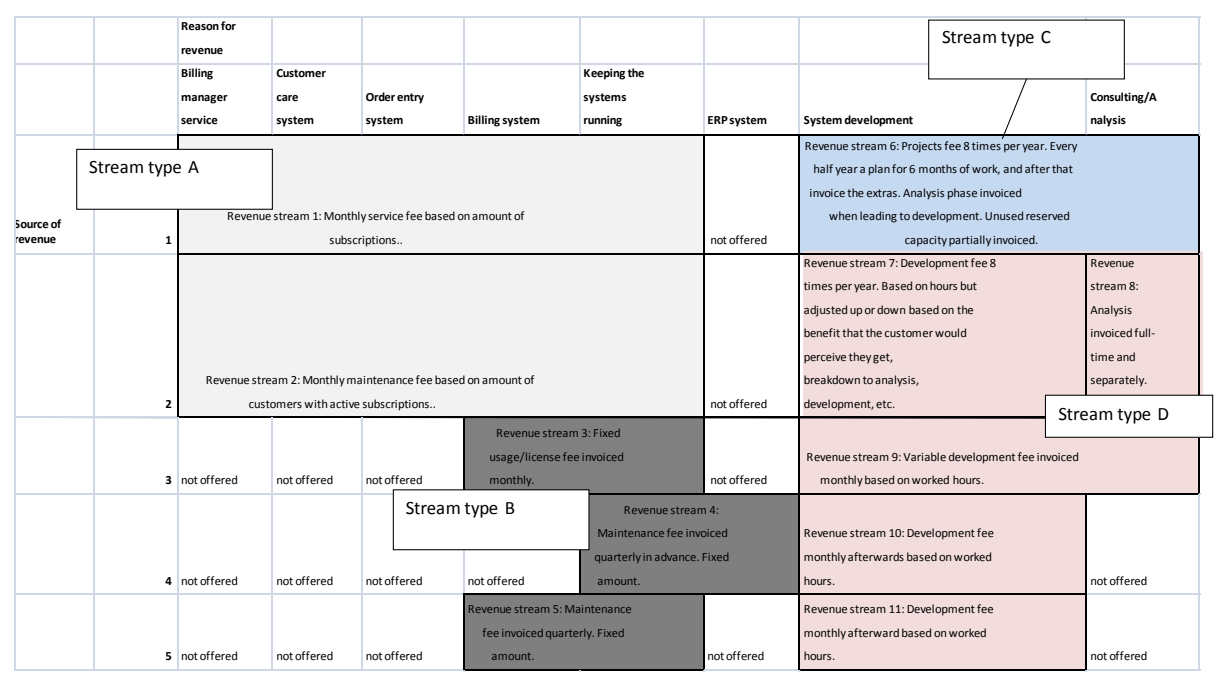

\subsection{Revenue Stream Types}

Stream type A consists of similarly structured revenue streams one and two. For both of them the method of payment is a fixed fee and a per unit price. For the stream 1 the unit is per active subscription and for stream 2 the unit is per end-customer (customer's customer) who has an active subscription handled by the system. In the interviews it was suggested that due to foreseeable changes in the industry the preferred model from vendor perspective was seen to be per service per customer which would better reflect the cost structure and allow the provider to benefit from the new services they might need to support by the system. In general the benefit of the invoicing tied to the growth of subscriptions was seen in having a shared goal of helping the customer grow, because it means more money for the vendor as well. Informant number five commented that "this is the best model I know".

Revenue stream type B included streams where the name people used for the model was different but the formula was the same, so it can be considered one stream type. The terms were either usage fee, license fee or maintenance fee, but they were all basically a fixed amount invoiced at a regular interval, either monthly or by quarterly, in advance or afterwards. Stream types A and B are basically the same in terms of offering: system usage right, and maintenance service. The terminology is interestingly causing problems. Informant six noted: "Because we charge license fee 
we have a lot of problems, because they see that they should get monthly development for free." Many people also felt that the future model should be more geared towards per unit based invoicing, because it offers a possibility to move toward value based invoicing away from cost based invoicing. Still, for new customers the downside is increased risks as informant 11 put it: "There is a challenge, because there are not that many of those and for us the cost of hardware doesn't go down. [In case of] minimum monthly payment, the volume can be too low, too much risk." This is one of the reasons why revenue stream type B exists alongside A. It was a safe choice at the initial selling stage.

Revenue stream type $\mathrm{C}$ is an interesting one, because it includes a guaranteed minimum purchase. Thus it could be called assured purchase volume and per unit invoicing. The way this is done in practice is that there is a planning session every half a year for the upcoming work which is partially guaranteed work. Informant 1 : "Current agreement offers us safety, that we have half a year work at a time. We can invoice 80 percent even if they would order nothing". Otherwise work is invoiced on a per unit price rate where the unit is the amount of worked hours.

Revenue stream type D is a plain per unit invoicing. Compared to stream type $\mathrm{C}$ the vendor takes the bigger risk. Pure per unit invoicing was considered easier to sell. The benefits of having an assured purchase volume were seen mainly due to the low transferability of excess capacity between the teams producing the offerings that generate the revenue streams. In the current case this low transferability problem is interestingly solved not by developing the organization but rather creating a revenue stream method that allows it.

Table 3. Contributions of revenue reasons to total revenue from each source

\begin{tabular}{|c|c|c|c|c|c|c|c|c|c|}
\hline & & $\begin{array}{l}\text { Reason for } \\
\text { revenue }\end{array}$ & & & & & & & \\
\hline & & $\begin{array}{l}\text { Billing } \\
\text { manager } \\
\text { service }\end{array}$ & $\begin{array}{l}\text { Customer } \\
\text { care } \\
\text { system }\end{array}$ & $\begin{array}{l}\text { Order } \\
\text { entry } \\
\text { system }\end{array}$ & $\begin{array}{l}\text { Billing } \\
\text { system }\end{array}$ & $\begin{array}{l}\text { Keeping } \\
\text { the } \\
\text { systems } \\
\text { running }\end{array}$ & $\begin{array}{l}\text { ERP } \\
\text { system }\end{array}$ & $\begin{array}{l}\text { System } \\
\text { develop } \\
\text { ment }\end{array}$ & $\begin{array}{l}\text { Consultin } \\
\text { g/Analysi } \\
\text { S }\end{array}$ \\
\hline \multirow[t]{5}{*}{$\begin{array}{l}\text { Source of } \\
\text { revenue }\end{array}$} & 1 & & & $70 \%$ & & & $\begin{array}{c}\text { not } \\
\text { offered }\end{array}$ & \multicolumn{2}{|c|}{$30 \%$} \\
\hline & 2 & & & $45 \%$ & & & $\begin{array}{c}\text { not } \\
\text { offered }\end{array}$ & $45 \%$ & $10 \%$ \\
\hline & 3 & not offered & not offere & not offere & \multicolumn{2}{|c|}{$50 \%$} & $\begin{array}{c}\text { not } \\
\text { offered }\end{array}$ & \multicolumn{2}{|c|}{$50 \%$} \\
\hline & 4 & not offered & not offere & not offere & not offere & & $7 \%$ & $83 \%$ & not offere। \\
\hline & 5 & not offered & not offere & not offere & & $\% \%$ & $\begin{array}{l}\text { not } \\
\text { offered }\end{array}$ & $5 \%$ & not offereı \\
\hline
\end{tabular}

\subsection{Revenue Contributions}

There was variation between the percentage contributions of revenue reasons to total revenue from each source. Table 3 summarizes these percentages and shows the differences between how much each revenue reason group contributes to the total 
income when comparing revenue sources to each other. The variation could be due to the lifecycle of the revenue source and one could guess that a new customer would require more development related activities whereas older customers would only need the service contract. There is initial support for such a conclusion, but the interviews indicated that other reasons like who made the original contract had more effect. Still, the interviews indicated that there was a goal to move away from stream types $\mathrm{C}$ and $\mathrm{D}$ towards stream types A and B. This was related to the fact that development work is dependent on doing more work: "In the development side the upside will not be very high. It always includes a lot of work." There was an element of unpredictability about future revenue. The fact that the buyer can decide upon buying something or not was seen bad and offering as a packaged service was preferred: "Rather predictability is better, so service fee [is preferred]." It could be said that revenue contributions overall are more likely to move towards the service oriented stream types $\mathrm{A}$ and $\mathrm{B}$ over time.

In sum, the undertaken analysis approach helped clarify the revenue stream variation within the case firm and gave support for the decision makers' business model understanding. During the interviews one of the informants had commented: "It's hard to tell which revenue stream contributes what. Because it seems the money goes into one bucket." Introducing the revenue stream type analysis can be the first step to alleviate the situation and help the firm in strategic decision making.

\section{Discussion}

The goal of this paper was to conduct exploratory research and answer the question about the constituents of revenue stream. The study suggests that a revenue stream has three main sub-components which are the source of revenue stream, the reason for the revenue stream and the method of revenue stream.

Table 4. Sub-components of revenue stream

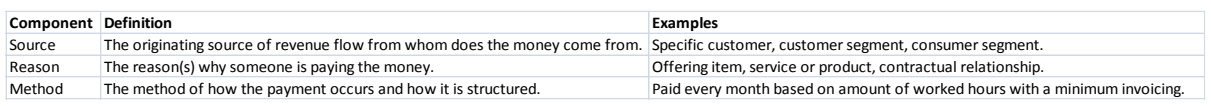

The second question to answer was how the revenue stream can be analyzed within a firm. It has been stated in previous literature that a business can produce one or more revenue streams from each source customer segment [17]. In this paper it has become evident that in a complex b2b setting, one revenue stream can be caused by several reasons of revenue each having different methods of revenue. In addition varying revenue streams can originate from similar sources. In the current b2b case the complexity was such that it was confusing to try to explain it without a clear structure or fit it into a too abstract model. It is suggested that revenue streams should be analyzed so that the method of getting paid is considered for each cell of a two dimensional matrix having two axis: source of the revenue stream and reason for the revenue stream. Only after this kind of analysis can the similarities in method of capturing revenue between the streams warrant a recombination into revenue stream types with similar attributes. Osterwalder [18] uses term stream type very broadly to mean type of economic activity used to generate income. Stream type is also often 
reduced to just listing examples such as: selling, lending, licensing, transaction cut and advertising [29]. This paper suggests, however, that this simplification is not necessary or even applicable in the current case and a revenue stream type within a firm should be defined based on a comparison of methods of revenue viewed through a source by reason matrix. Thus, it is suggested that a revenue stream type describes the method of revenue for streams originating from a similar revenue source for a similar reason for revenue. Further a full explanation of a revenue model means describing all the revenue stream types used.

Based on the empirical analysis the following hypothesis is suggested for future testing: When analyzing the revenue streams of a business model, it is necessary to analyze them separately based on source (from whom does the revenue originate from?) and reason (on what offering is the invoicing based on?) dimensions. Further it is suggested that analyzing the method of revenue within these "source-reason" cells allows the detection of unique revenue stream types which define the nature of the business model in regards of revenue. This kind of matrix cell representation is suggested to describe the firm's revenue mix much better than for example the revenue mix concept of Stähler [30] which is defined as the sum of all sources of revenue the firm has. It is suggested that revenue mix concept should rather be a description of revenue stream types in all three mentioned dimensions not just the one.

Because of the demonstrated incoherence of revenue aspects relating to business model in the existing literature, a decomposition of the revenue stream concept was attempted. This paper provides support to the usefulness of the concept revenue stream and suggests its applicability also to the analysis of $b 2 \mathrm{~b}$ software service businesses. Because only one specific context of $b 2 b$ software service business was considered, further study should be made in other contexts to compare the findings and investigate the suggested decomposition to enable more general theoretical propositions. Here the context was $\mathrm{b} 2 \mathrm{~b}$, because of the case selection, but it might be possible to expand the findings towards $\mathrm{b} 2 \mathrm{c}$ in the future.

This paper contributed to the business model research by defining three constituents of a revenue stream and introducing the concept of revenue stream type as a combination of revenue streams with similar method of revenue. For management practitioners a tool was presented for analyzing revenue aspects of the business model. The presented decomposition could be used when investigating for example the profitability of different revenue streams to gain a more fine grained analysis. Managers can use this systematic approach to better understand the business and describe and visualize the revenue streams involved.

The suggestion for future business model research is to promote the money flow i.e. revenue stream as the central concept around which an analysis of a business model should be built upon, because a business by definition has to generate revenue in order to be viable on the long term. Therefore, following the money is a good idea.

\section{References}

1. Petrovic, O., Kittl, C., Teksten, R.: Developing business models for ebusiness. Available at SSRN 1658505 (2001) 
2. Al-Debei, M.M., Avison, M.: Developing a unified framework of the business model concept. European Journal of Information Systems. 19(3), 359-376 (2010)

3. Osterwalder, A., Pigneur, Y.: An e-business model ontology for modeling e-business. In: 15th Bled Electronic Commerce Conference, pp. 17-19. Bled (2002)

4. Pateli, A., Giaglis, G.: A framework for understanding and analysing e-business models. In: Bled Electronic Commerce Conference. Bled (2003)

5. Mahadevan, B.: Business models for Internet-based e-commerce. California management review, 42(4), 55-69 (2000)

6. Rajala, R., Rossi, M., Tuunainen, V.K.: A framework for analyzing software business models. In: ECIS, pp. 1614-1627 (2003)

7. Weill, P., Vitale, M.R. Place to space: Migrating to eBusiness Models. Harvard Business Press (2001)

8. Alt, R., \& Zimmermann, H. D.: Preface: introduction to special section-business models. Electronic Markets, 11(1), 3-9 (2001)

9. Magretta, J.: Why Business Models Matter. Harvard Business Review, 80(5), 86-92 (2002)

10. Afuah, A., Tucci, CL: Internet Business Models and Strategies: Text and Cases. McGrawHill, Boston (2001)

11. Gordjin, J.: Comparing two business model ontologies for designing e-business models and value constellations. Technical report, 18th Bled eConference eIntegration in action (2005)

12. Rédis, J.: The impact of business model characteristics on IT firms' performance. International journal of business 14.4: 291-307 (2009)

13. Nenonen, S., Storbacka, K.: Business model design: conceptualizing networked value cocreation. International Journal of Quality and Service Sciences, 2(1), 43-59 (2010)

14. Schief, M., Buxmann, P.: Business models in the software industry. In System Science (HICSS), 2012 45th Hawaii International Conference on (pp. 3328-3337). IEEE (2012)

15. Ojala, A., Tyrväinen, P.: Revenue models in cloud computing. In E. Prakash(Ed.), Proceedings of 5 th Computer Games, Multimedia \& Allied Technology Conference (CGAT 2012) (pp. 114-119). Singapore: GSTF (2012)

16. Zott, C., Amit, R.H.: Designing your future business model: an activity system perspective. Social Science Research Network Working Paper Series (2009)

17. Osterwalder, A., Pigneur, Y. : Business model generation-a handbook for visionaries, game changers, and challengers. Wiley, New York (2010)

18. Osterwalder, A.: The business model ontology: A proposition in a design science approach. Institut d'Informatique et Organisation. Lausanne, Switzerland, University of Lausanne, Ecole des Hautes Etudes Commerciales HEC, 173 (2004)

19. Shafer, S.M., Smith, H.J., Linder, J.C.: The power of business models. Business horizons, 48(3), 199-207 (2005)

20. Linder, J., Cantrell, S.: Carved in water: Changing business models fluidly. Accenture Institute for strategic change (2000).

21. Rajala, R., Rossi, M., Tuunainen, V.K., Vihinen, J.: Revenue Logics of Mobile Entertainment Software-Observations from Companies Producing Mobile Games. JTAER, 2(2), 34-47 (2007)

22. Giesen, E., Berman, S.J., Bell, R., Blitz, A.: Three ways to successfully innovate your business model. Strategy \& Leadership, 35(6), 27-33 (2007)

23. Chesbrough, H.: Business model innovation: it's not just about technology anymore. Strategy \& leadership, 35(6), 12-17 (2007)

24. Yin, R.K.: Case study research: Design and methods (Vol. 5) Sage (2003)

25. Yin, R.K.: Case study research: Design and methods. 2nd edition. Applied social research method series, vol 5. Sage publications (1994)

26. Eisenhardt, K.M.: Building theories from case study research. Academy of management review, 14(4), 532-550 (1989) 
27. Luoma, E., Frank, L., Pulkkinen, M.: Overview of telecom operator software market. In Vertical Software Industry Evolution (pp. 35-42). Physica-Verlag HD (2009)

28. Kohlbacher, F.: The use of qualitative content analysis in case study research. In Forum Qualitative Sozialforschung/Forum: Qualitative Social Research (Vol. 7, No. 1) (2006)

29. Scheithauer, G., Wirtz, G.: Business modeling for service descriptions: a meta model and a UML profile. In Proceedings of the Seventh Asia-Pacific Conference on Conceptual Modelling-Volume 110 (pp. 79-88). Australian Computer Society, Inc. (2010)

30. Stähler, P.: Business models as a unit of analysis for strategizing. Online: http://www.scribd.com/doc/34770740/Business-Models-as-a-unit-of-Analysis-forStrategizing. Referenced on 7.1.2013 (2002) 